\title{
Milking-to-Milking Variability for Milk Yield, Fat and Protein Percentage, and Somatic Cell Count
}

\author{
M. A. Quist, ${ }^{1}$ S. J. LeBlanc, ${ }^{*}$ K. J. Hand,† D. Lazenby,† F. Miglior, $₫ \S$ and D. F. Kelton* \\ *University of Guelph, Ontario Veterinary College, Guelph, Ontario, Canada, N1G 2W1 \\ †CanWest Dairy Herd Improvement Corporation, Guelph, Ontario, Canada, N1K 1E5 \\ $\ddagger$ Agriculture and Agri-Food Canada-Dairy and Swine Research and Development Centre, Sherbrooke, Québec, Canada, J1M 1 Z3 \\ §Canadian Dairy Network, Guelph, Ontario, Canada, N1G 4T2
}

\begin{abstract}
The main objectives were to analyze milking-to-milking variability in milk yield, fat and protein percentages, and somatic cell count (SCC). Additional objectives were to investigate the factors that affect variation in milk fat percentage and to study the seasonal variations in milk, fat, and protein yields and SCC. A total of 16 farms (14 milked $2 \times$ and 2 milked $3 \times$ ) across Canada participated in a 5-d milk-sampling study, with 27,328 milk samples collected and analyzed for fat and protein yields and SCC. Descriptive statistics for both $2 \times$ and $3 \times$ herds for milk yield and fat and protein percentages followed a typical pattern throughout lactation, and the somatic cell linear scores were higher in early lactation for first-lactation cows (4.7 vs. 3.8) but were higher at the end of lactation for cows in second lactation or greater (5.1 vs. 4.9). The $2 \times$ herds had higher milk yields in the morning ( $\sim 17$ vs. $\sim 14 \mathrm{~kg}$ ), whereas the $3 \times$ herds had the lowest milk yields in the morning, and yields peaked at the evening milking ( $\sim 9$ vs. $\sim 11.2 \mathrm{~kg}$ ). A herd management questionnaire was distributed to participating producers to investigate the relationship between management variables and variations in milk fat percentage over the 5-d sampling period. Data from the questionnaire determined that milking period had a significant effect on milk fat in $2 \times$ herds, with fat percentage $1.11 \%$ lower in the morning compared with the evening milking period. Seasonal differences in milk, fat, and protein yields were investigated in 910 cows on 3 farms, with 5,517 fat and 5,534 protein samples. The seasonal differences in fat yield [summer $=1.02 \pm 1.05$ $\mathrm{kg} / \mathrm{d}(\mathrm{SEM}) ;$ winter $=1.19 \pm 1.05 \mathrm{~kg} / \mathrm{d}]$ and protein yield $($ summer $=0.85 \pm 1.05 \mathrm{~kg} / \mathrm{d}$; winter $=0.96 \pm 1.05 \mathrm{~kg} / \mathrm{d})$ were significant only for first lactation. Understanding the variability in milk yield, fat and protein percent-
\end{abstract}

Received March 9, 2007.

Accepted March 18, 2008.

${ }^{1}$ Corresponding author: mquistmoyer@gmail.com ages, and SCC is important when making management decisions and in milk-recording programs.

Key words: milking-to-milking variability, feed management, seasonal effect

\section{INTRODUCTION}

Participation in DHI milk testing involves regularly recording a milk weight and collecting a composite milk sample from individual cows to be used as a 24 -h yield estimate of each of milk, fat, protein, and SCC in the multiple-trait prediction model for lactation yield prediction. Test schemes offered by DHI organizations include sampling all milking periods of the 24-h test day; the alternate a.m.-p.m. scheme involving a single milking sampled each test day, alternating morning and evening from test to test; and an owner-sampler scheme, with the producer collecting the milk samples each test day. The increase in flexibility of test-day plans has encouraged producers to continue to participate in milk-recording programs. Much research has gone into evaluating alternative testing schemes to ensure that 24-h yield is being estimated accurately.

Previous studies have reported that when the interval between milkings is equal, morning milk yield tends to be higher by 0.10 to $0.65 \mathrm{~kg}$ because of natural diurnal variation (Everett and Wadell, 1970; Putnam and Gilmore, 1970; Gilbert et al., 1973). It has been reported that protein percentage has less day-to-day than milking-to-milking variation, with protein percentage 0.09 points higher in the evening. Fat percentage has more milking-to-milking variation than protein percentage, with fat percentage 0.32 points higher in the evening (Gilbert et al., 1973). These results confirmed the need for correction factors to minimize bias when using the monthly a.m.-p.m. testing scheme to calculate lactation yield estimates.

The effects of diet and the frequency of feeding on digestion, milk production, and energy utilization have been studied extensively (Sutton et al., 1985; Klusmeyer et al., 1990). Milk components can be al- 
tered rapidly through changes in nutrition; however, fat is the most sensitive to ration changes (Sutton, 1989; Jenkins and McGuire, 2006). A higher feeding frequency improved ruminal fermentation by avoiding bursts of high fermentation activity after a large feeding (Sutton et al., 1985; Klusmeyer et al., 1990). Sutton et al. (1985) reported that more frequent feeding resulted in an increase in milk fat yield. The Canadian quota system for milk production is based on kilograms of milk fat produced; therefore, studying factors that can influence the milk fat test is of high priority.

Producers rely on monthly SCC results from DHI reports as a tool to monitor the udder health of the herd and individual animals (Dohoo and Meek, 1982; Harmon, 1994). Somatic cell counts can indicate subclinical mastitis in herds or individuals (Cullen, 1967; Dohoo and Meek, 1982). Infection status has the largest effect on SCC, even if the infection is short term. There is variation in SCC throughout milking, as well as diurnal variation from milking to milking (Cullen, 1967; Dohoo and Meek, 1982). Diurnal variation consists of higher SCC in the evening than in the morning milkings, and the difference is assumed to be due to the interval between milkings (Cullen, 1967; Syrstad and Ron, 1978).

Season affects milk yield, component percentages, and SCC. Ng-Kwai-Hang et al. (1984) and Sargeant et al. (1998) reported an inverse relationship between milk yield and component percentages, with summer milk production being higher but percentages of fat and protein being reduced compared with production in the fall and winter months. Ng-Kwai-Hang et al. (1984) concluded that milk and component yield variations were dependent on environmental conditions. The common seasonal trend in SCC in the Northeast and Midwest of North America involves peaking in the late summer and decreasing to a low in the winter months (Bodoh et al., 1976; Salsberg et al., 1984). Nevertheless, Ng-Kwai-Hang et al. (1984) found that SCC peaked in the winter months and was at a low in summer months, which was attributed to the cows being kept indoors in the winter and on pasture in the summer. Seasonal variability was taken into account in calculating the multiple-trait prediction yield estimate by considering the month of test day (Schaeffer and Jamrozik, 1996).

The main objective of this study was to describe the milking-to-milking variation in milk yield, fat and protein percentages, and SCC. Additional objectives were to investigate the factors that affect variation in milk fat percentage, and to study the seasonal variations in milk, fat, and protein yields and SCC.

\section{MATERIALS AND METHODS}

\section{Data Collection}

A total of 8 herds from Alberta and 8 herds from Ontario, Canada, were selected based on their ability and willingness to supply the required data. Requirements for inclusion were enrollment in CanWest DHI (Guelph, Ontario, Canada) milk recording and being equipped with electronic milk meters and electronic cow identification interfaced with Dairy Comp 305 (Valley Agricultural Software, Tulare, CA) in the milking parlor. Individual cow milk weights and composite samples were collected at every milking for 5 consecutive days between October 2004 and September 2005. Three Ontario herds from this sampling period (summer sampling) were selected to participate in a second 5-d sampling period between February and March 2006 (winter sampling). Farm employees, DHI technicians, or project staff collected the samples. The DHI vial number and corresponding cow identification number were recorded. Milk was collected into standard DHI sample vials and sent to the DHI laboratory (Guelph, Ontario, Canada) for analysis of fat, protein, and SCC. Collection of the daily milk weights from the on-farm computer continued throughout the sampling period.

\section{Herd Management Questionnaire}

Herd management factors and their relationship with variation were investigated with a questionnaire mailed to the 16 participating farms. The questionnaire included basic management practices relative to milking times and feeding routines, and the use of on-farm computer software systems. The purpose was to gather information that could be used to examine whether there was any relationship between feeding management and short-term variability in milk fat yields. Producers reported the time and frequency throughout the day that fresh feed was fed and pushed up to the milking cows.

\section{Statistical Analysis}

Mean Milk Yield, Milk Component Yields, and SCC. The milk component results and SCC were merged with daily milk yields into a single data set for analysis by the SAS software program (SAS Institute, 2000). The mean milk yield, milk component yields, and SCC from all cows were calculated at each milking over the 5-d sampling period. The SCC was weighted by the mean milk production at each milking to account for the dilution of SCC by milk yield. The data were divided into lactations 1,2 , and $\geq 3$, and within 


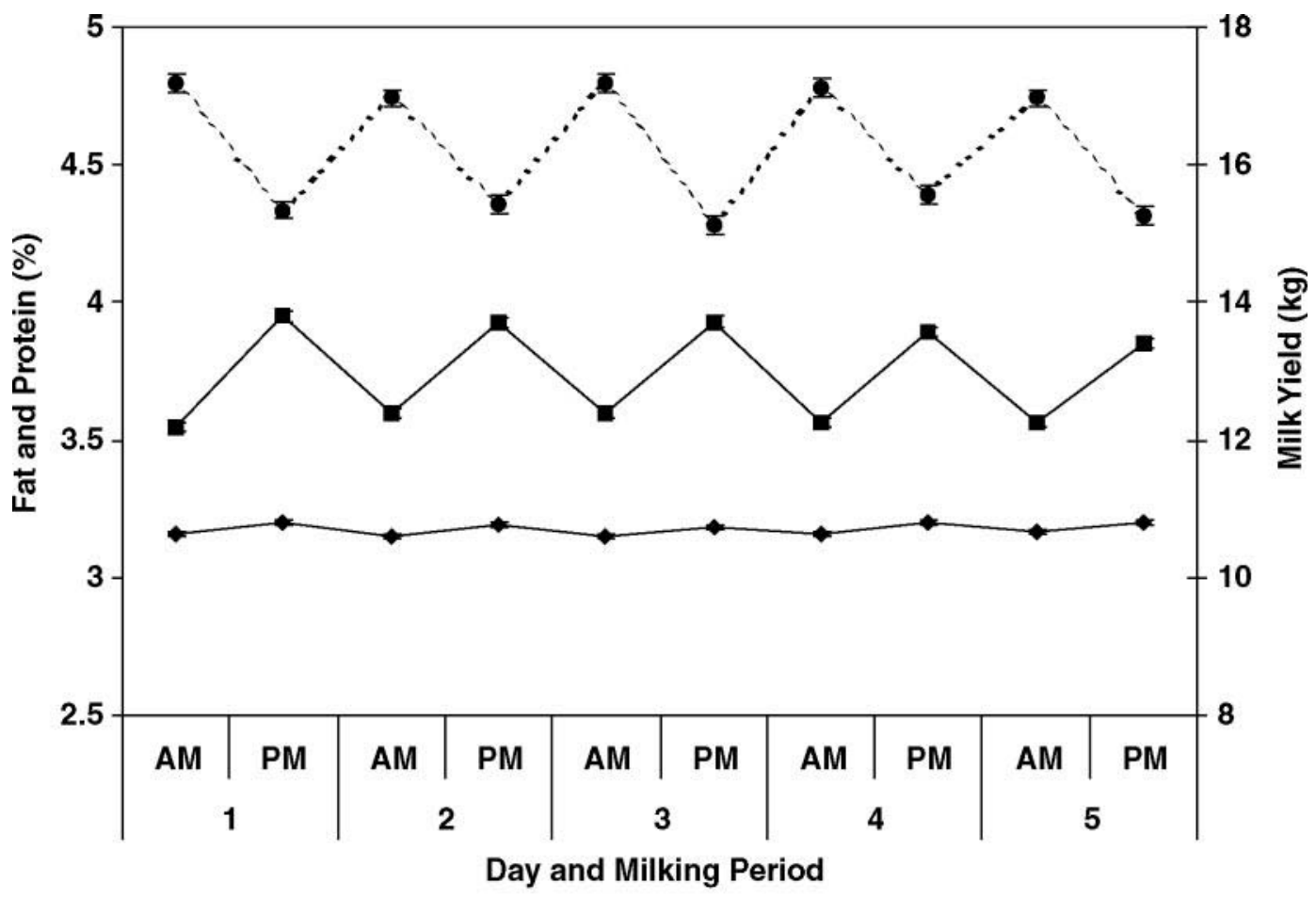

Fat $\longrightarrow$ Protein $\ldots \bullet \cdot$... Milk Yield

Figure 1. Mean $\pm \mathrm{SE}$ of 14 herds milked $2 \times$ for milk yield and fat and protein percentages for each milking period over a 5 -d period.

each lactation group, DIM were categorized in 3 stages (5 to 60,61 to 120 , and 121 to 305 DIM) for a total of 9 classes, and were analyzed separately. The 3 stages within each lactation, 5 to 60,61 to 120 , and 121 to 305 DIM, are referred to as early, mid, and late lactation, respectively.

Descriptive Statistics for Milk Yield, Milk Component Yields, and SCC. On the basis of milking frequency, farms were divided into 2 groups and their data were analyzed separately. Fourteen herds milked twice daily $(2 \times)$ and 2 herds milked 3 times daily $(3 \times)$. Descriptive statistics, consisting of the mean, standard deviation, and 10th, 50th, and 90th percentiles were derived for milk, fat, and protein yields and SCC. A somatic cell linear score (LS) was calculated (Raubertas and Shook, 1982) to avoid bias of the mean by extremely high raw SCC. The mean and 10th, 50th, and 90th percentiles were calculated for LS. Descriptive statistics were examined to identify any patterns that might exist among the lactation groups and to highlight any potential values outside biological limits. The milking period (morning, afternoon, or evening) outliers were identified, when deemed appropriate, on a case-by-case basis, and erroneous values were deleted and replaced with the mean of the values of the remaining milkings.
Data Analysis of the Herd Management Questionnaire. The feed management data from the questionnaire were entered into a database and merged with the 5-d sampling database in SAS (SAS Institute, 2000 ), and $2 \times$ and $3 \times$ herds were analyzed separately. The standardized residuals for fat percentage were not normally distributed; therefore, fat percentage was transformed to its natural logarithm for analysis. Fixedeffect variables tested in the model were sample day, lactation number, milking period (morning, afternoon, and evening), number of times fresh feed was delivered over $24 \mathrm{~h}$, and number of times feed was pushed up to cows over $24 \mathrm{~h}$. The random effect of herd was included in the model. Analysis was performed in a backward stepwise elimination procedure. Variables were left in the final model based on a significance of $P<0.05$.

Variance Components of the Herd Management Questionnaire. To determine the factors that contributed most to the variability in mean herd fat yield in the previous model, variance components attributable to herd, sample day, and milking (morning, afternoon, and evening) were estimated. Variance components were determined with all herds together, as well as separately by milking frequency $(2 \times$ and $3 \times)$.

Analysis of Seasonal Effects. To measure seasonal effects, linear regression of fat and protein yields per 

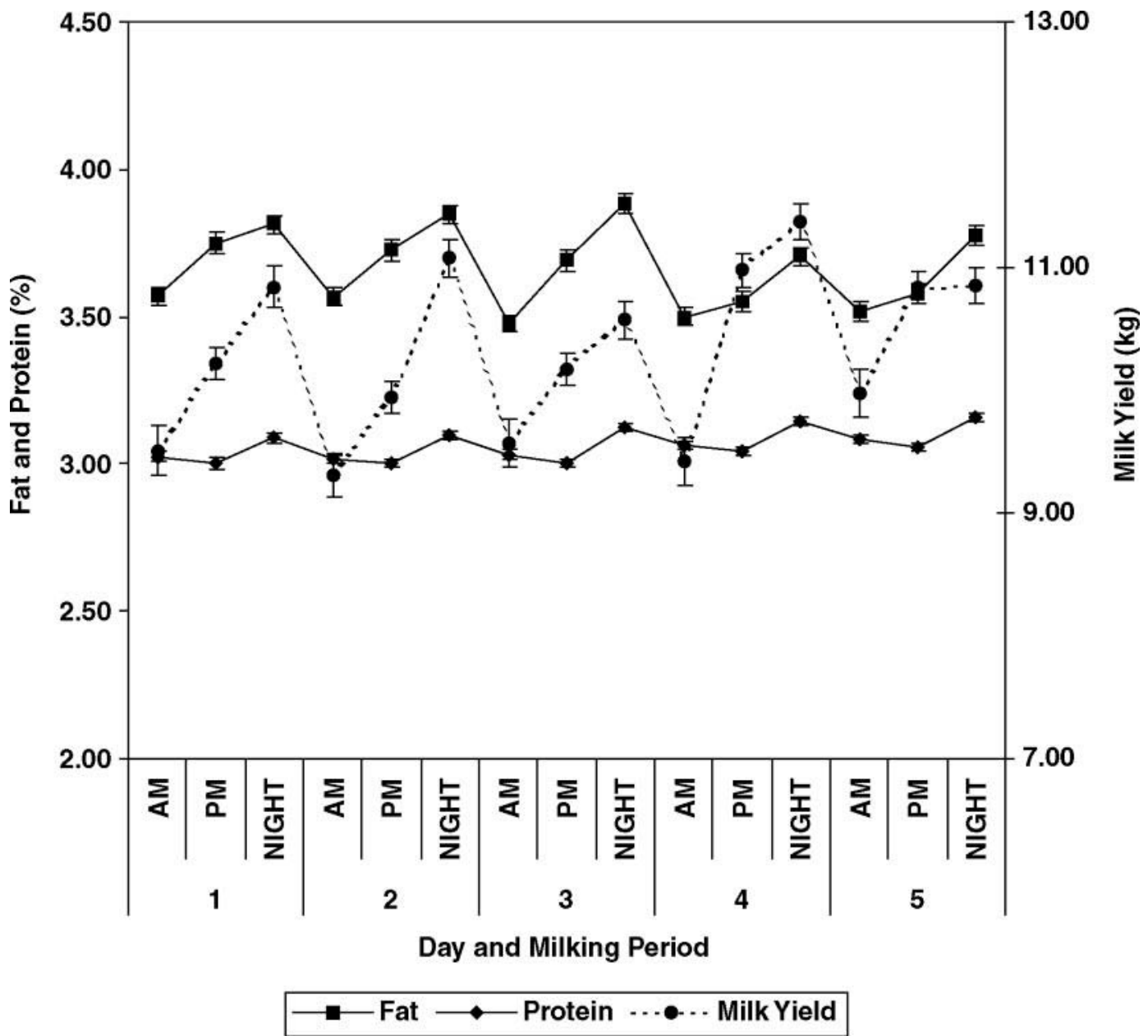

Figure 2. Mean $\pm \mathrm{SE}$ of 2 herds milked $3 \times$ for milk yield, and fat and protein percentages for each milking period over a 5-d period.

day was performed with fixed and random effects. The $2 \times$ and $3 \times$ herds were analyzed together. The standardized residuals for fat and protein percentages were not normally distributed; therefore, fat and protein percentages were transformed to the natural logarithm for analysis. Fixed effects tested in the model were milking frequency $(2 \times$ or $3 \times)$, season (winter or summer), lactation number $(1,2, \geq 3$ ), and DIM (early, mid, or late). Interactions terms included lactation $\times$ DIM, lactation $\times$ season, and DIM $\times$ season. The random effects included in the model were herd, cow, and cow as a repeated measure. Analysis was performed in a backward stepwise elimination procedure. Variables were left in the model based on a significance of $P<$ 0.05. All statistical models were analyzed by PROC MIXED (SAS Institute, 2000).

\section{RESULTS}

The mean herd sizes of farms participating were 163 cows from Alberta and 185 cows from Ontario for the
$2 \times$ herds, and 399 cows for the $3 \times$ herds. Mean production of participating $2 \times$ herds for milk was $32.4 \mathrm{~kg} / \mathrm{d}$, fat was $3.68 \% / d$, and protein was $3.15 \% / d$. The mean production of the $3 \times$ herds for milk was $31.14 \mathrm{~kg} / \mathrm{d}$, fat was $3.70 \% / d$, and protein was $3.08 \% / d$. A total of 26,949 milk samples were collected and analyzed. Means over the 5-d sampling period of milk yield and milk component percentages of fourteen $2 \times$ herds $(n=1,913)$ and two $3 \times$ herds $(\mathrm{n}=530)$ are shown in Figures 1 and 2 , respectively, along with mean SCC in Figures 3 and 4. The $2 \times$ herds had peak daily yields in the morning (Figure 1 ), whereas the $3 \times$ herds had peak yields in the evening and the lowest yields in the morning (Figure 2).

Although the milking-to-milking graphs of the sampling period provide a good illustration of the milk yield, fat and protein percentage, and SCC variation, they do not distinguish between lactation number and stages of DIM. The descriptive statistics for milk, milk components, and LS per milking offer a comparative view of the early, mid, and late stages of DIM for each 


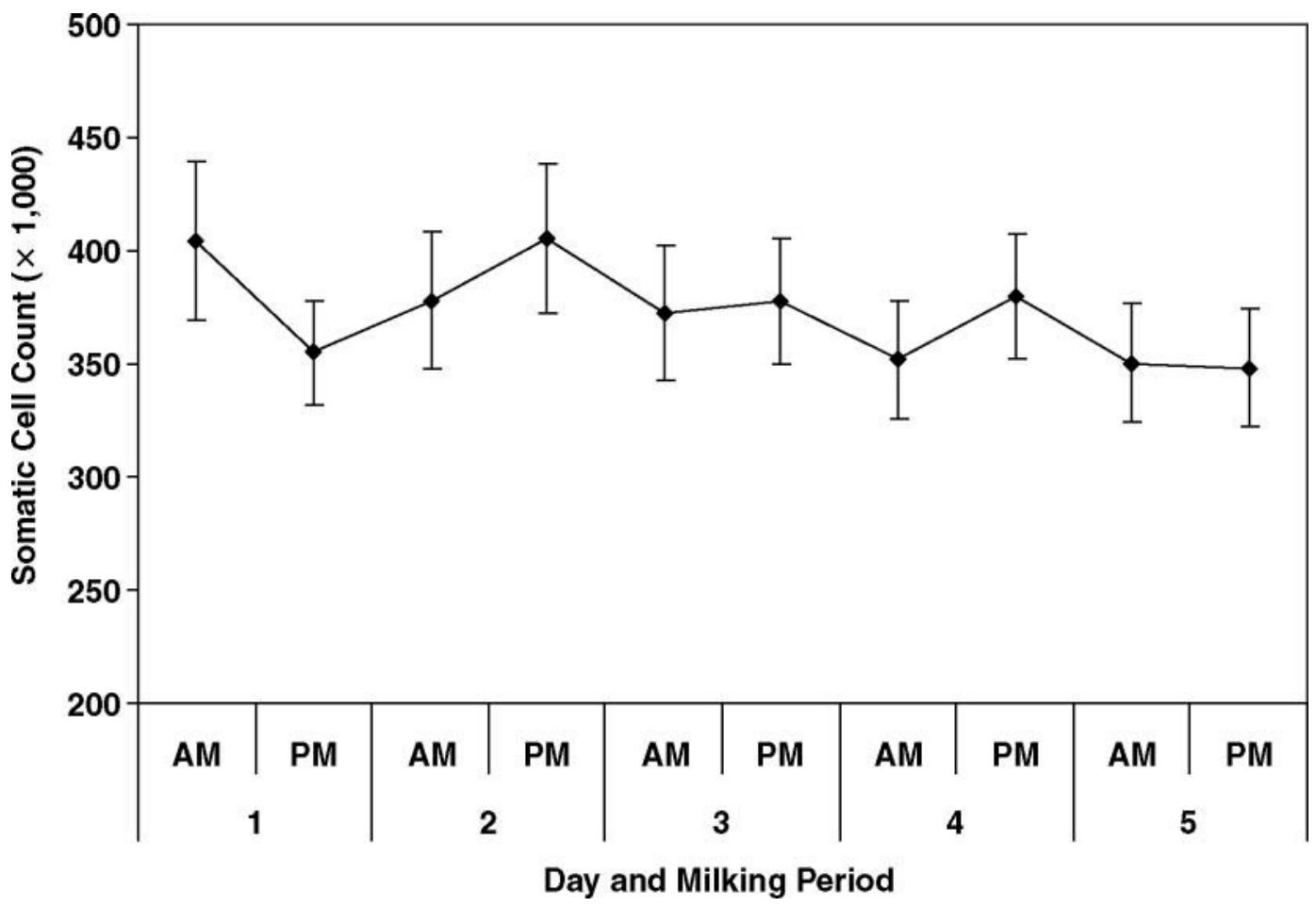

Figure 3. Mean $\pm \mathrm{SE}$ of 14 study herds milked $2 \times$ for SCC weighted with milk yield for each milking period over a 5 -d period.

lactation number for the $2 \times$ and $3 \times$ herds separately (Tables 1 and 2).

Herd Management Questionnaire. The herd management questionnaire was returned by 14 of the 16 participating farms, 2 of those being $3 \times$ herds. Feed management data were used to evaluate the variation in milk fat percentage over $5 \mathrm{~d}$. In $2 \times$ herds, interactions between fresh feed and pushed-up feed variables were not significant $(P=0.49)$; therefore, the main-effects model was evaluated. The final $2 \times$ linear regression model for milk fat percentage included the milking period (morning vs. evening) variable $(P<$ 0.01 ). The morning milking coefficient was -0.10 , indicating that at the morning milking, fat percentage was 0.10 points, or $1.11 \%$, lower compared with the evening milking. The graphs of variation correspond to the lower fat percentage in the morning versus evening milking (Figures 1 and 2). Because there were only 2 herds in the $3 \times$ group, fixed effects were confounded and the model could therefore not be analyzed.

Variance Components of the Herd Management Questionnaire. Percent contributions from variance components (herd, residual, milking, and day) to the diurnal variation over $5 \mathrm{~d}$ of milk fat production for $2 \times$ herds were $41.9,36.0,22.1$, and zero, respectively, and for $3 \times$ herds were $44.2,34.5,21.4$, and zero, respectively. Across both $2 \times$ and $3 \times$ herds, the contribution to the total variance made by each herd, milking, and day was similar. Herd contributed the most variance, followed by the residual variable and then milking. The effect of day was zero for all data sets, indicating that day was a negligible source of variability.

Seasonal Effects. Seasonal differences in milk, fat, and protein yields for 3 participating farms are illustrated in Figures 5 and 6 for $2 \times$ and $3 \times$ herds, respectively. Fat and protein yields were very similar in both seasons for all herds, but the milk yield showed the most variation, with the $2 \times$ herds having higher yields in the summer and the $3 \times$ herd having a slightly higher yield in the winter. The weighted SCC showed a higher SCC in summer in the $2 \times$ herds (Figure 7 ), whereas there was no clear seasonal pattern in the $3 \times$ herd (Figure 8).

The least squares means and linear regression analysis included 910 cows, with a total of 5,517 fat and 5,534 protein observations. Interactions between lactation number and season and lactation number and DIM were significant $(P<0.01)$ for both fat and protein yield. Lactation number and season were associated with fat and protein yields (Table 3), and results indicated that in the first and second lactations, fat and protein yields were slightly lower in summer compared with winter and with lactation $\geq 3$. The seasonal differences in fat yield [summer $=1.02 \pm 1.05 \mathrm{~kg} / \mathrm{d}(\mathrm{SEM})$; winter $=1.19$ 


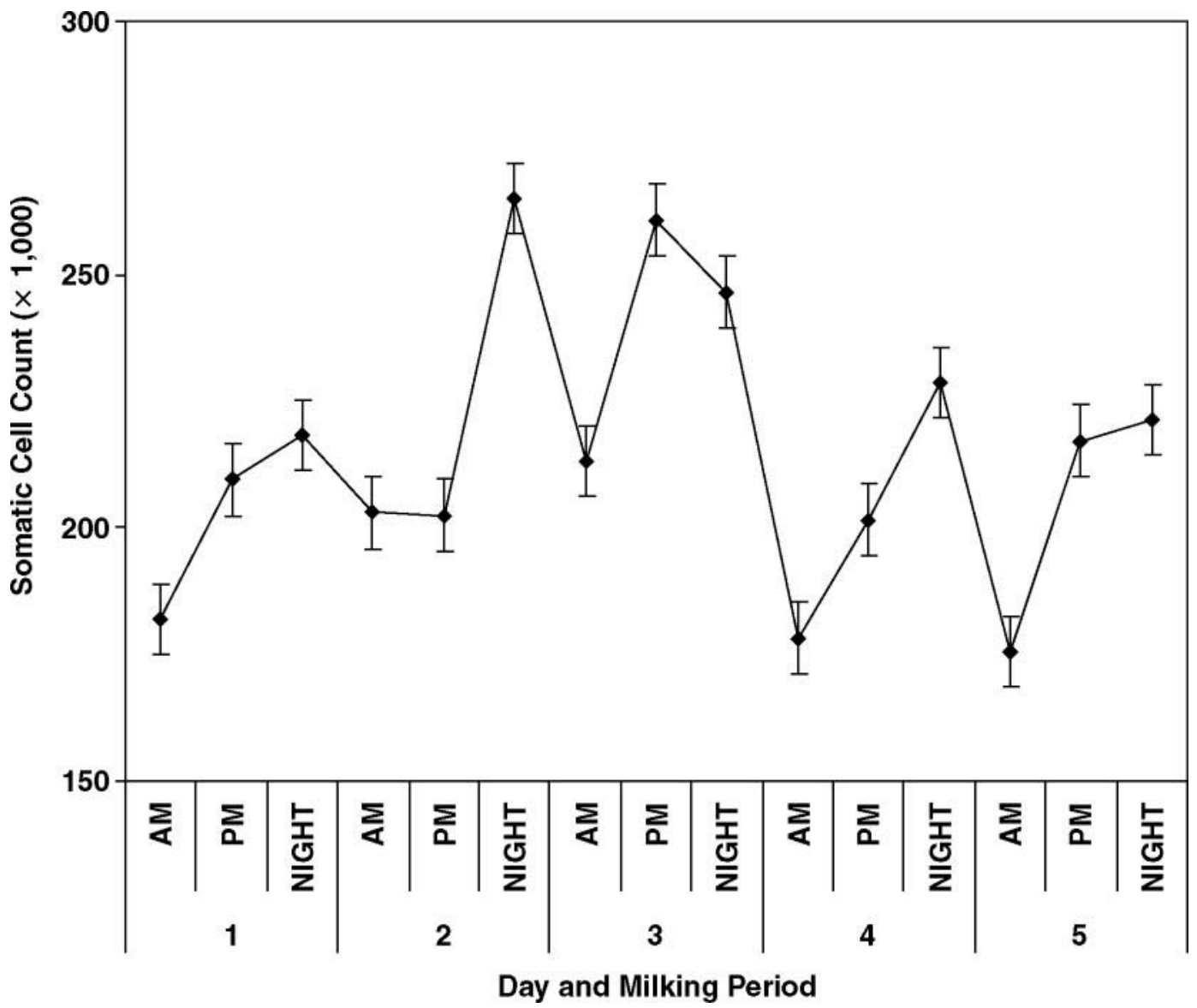

Figure 4. Mean \pm SE of 2 herds milked $3 \times$ for SCC weighted with milk yield for each milking period over a 5 -d period.

$\pm 1.05 \mathrm{~kg} / \mathrm{d}]$ and protein yield (summer $=0.85 \pm 1.05$ $\mathrm{kg} / \mathrm{d}$; winter $=0.96 \pm 1.05 \mathrm{~kg} / \mathrm{d})$ were significant only for the first lactation $(P<0.001)$.

\section{DISCUSSION}

\section{Variability of Milk and Milk Components}

The diurnal pattern of milk yield in the $2 \times$ herds (Figure 1) showed a higher yield in the morning than in the afternoon, which agrees with findings from previous studies (Everett and Wadell, 1970; Putnam and Gilmore, 1970; Gilbert et al., 1973). In 2 of these previous studies, however, a 12-h milking interval was used, whereas in the present study the milking interval was not accounted for. The $3 \times$ study herds (Figure 2 ) had an opposite diurnal pattern, with the lowest milk yield in the morning and with milk yield increasing through the afternoon milking to peak at the evening milking. The morning milk yield was lower than the afternoon milk yield despite 100 fewer cows being milked in the afternoon. Yet the group of cows not milked in the af- ternoon on one farm consisted of low-yielding late-lactation cows, which would likely reduce the mean yield at that milking. In both the $2 \times$ and $3 \times$ herds, the milk yield pattern displayed some inconsistency at some point throughout the 5 -d sampling period. This could have been due to various environmental factors, such as extreme changes in environmental temperatures, or to management events, such as a change in routine or the introduction of new herdmates on the study farms. Unfortunately, data on such events during the study period were not recorded.

The patterns of fat and protein variation of the $2 \times$ herds (Figure 1) were consistent with those of Gilbert et al. (1973), who found that fat and protein percentages were higher in the evening milkings. Although their results involved only a $2 \times$ herd milked on a $12-\mathrm{h}$ interval, the $3 \times$ study herds had comparable variation, with some inconsistency in the 5-d diurnal pattern (Figure 2). In the $3 \times$ herds, both fat and protein peaked in the evening; however, fat increased from the morning milking throughout the day to peak at the evening milking, whereas protein tended to increase from a low 
Table 1. Descriptive statistics (mean, SD, P10, P50, P90 = 10th, 50th, 90th percentiles) of milk yield, fat and protein percentages, and somatic cell linear score (LS) per milking period (early, mid, or late DIM) from the 5 -d milk sampling period of the $2 \times$ study herds

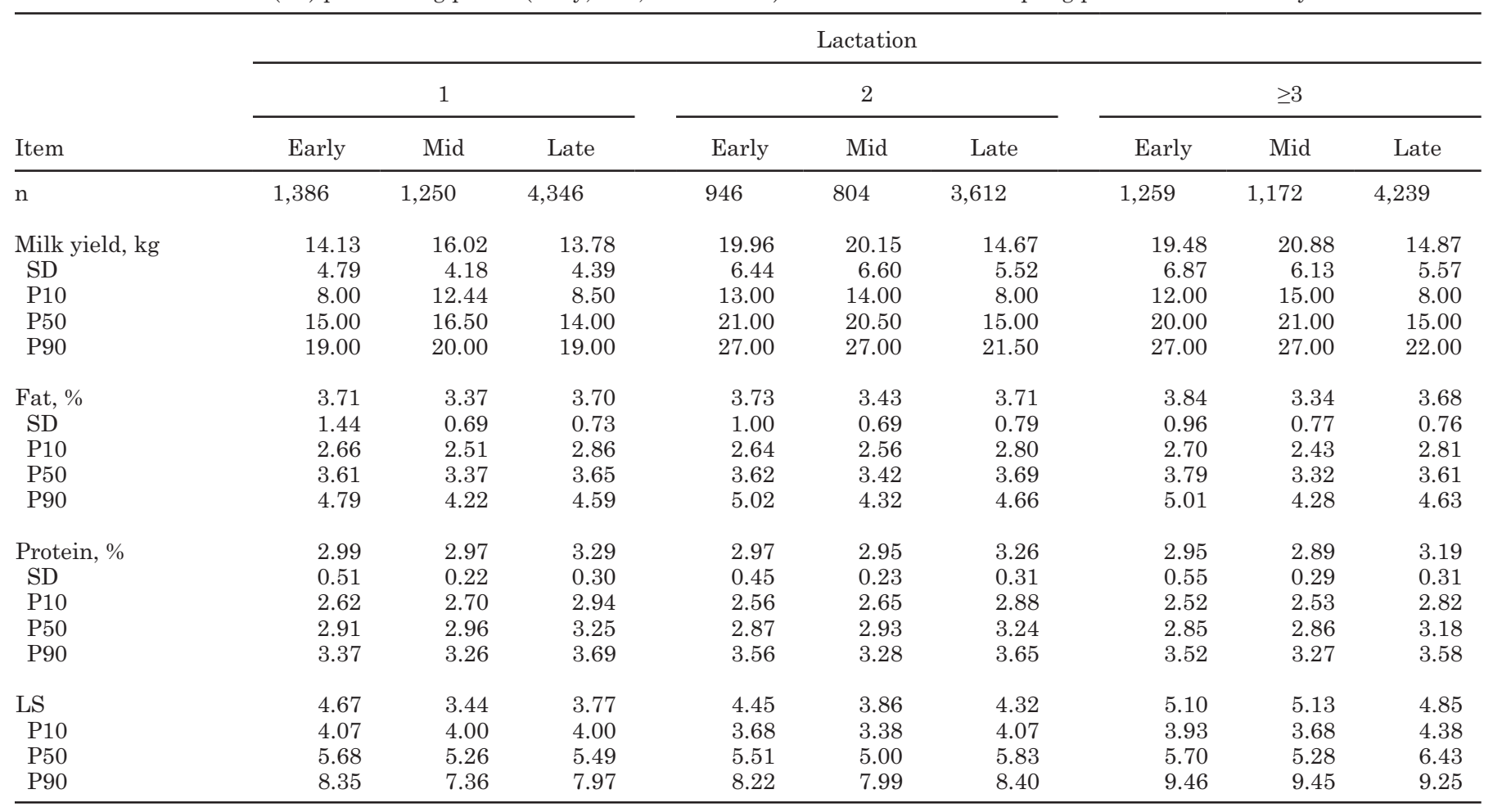

Table 2. Descriptive statistics (mean, SD, P10, P50, P90 = 10th, 50th, 90th percentiles) of milk yield, fat and protein percentages, and somatic cell linear score (LS) per milking period (early, mid, or late DIM) from the 5-d milk sampling period of $3 \times$ study herds

\begin{tabular}{|c|c|c|c|c|c|c|c|c|c|}
\hline Item & \multicolumn{9}{|c|}{ Lactation } \\
\hline $\mathrm{n}$ & 480 & 312 & 2,426 & 551 & 529 & 1,354 & 485 & 550 & 1,267 \\
\hline $\begin{array}{l}\text { Milk yield, kg } \\
\text { SD } \\
\text { P10 } \\
\text { P50 } \\
\text { P90 }\end{array}$ & $\begin{array}{r}10.35 \\
2.71 \\
7.00 \\
10.00 \\
14.00\end{array}$ & $\begin{array}{r}10.51 \\
2.66 \\
7.50 \\
10.50 \\
13.50\end{array}$ & $\begin{array}{r}8.57 \\
3.31 \\
5.00 \\
9.00 \\
12.00\end{array}$ & $\begin{array}{r}12.69 \\
3.16 \\
8.50 \\
13.00 \\
16.50\end{array}$ & $\begin{array}{r}12.59 \\
3.22 \\
8.00 \\
12.50 \\
16.50\end{array}$ & $\begin{array}{r}9.28 \\
4.31 \\
2.50 \\
9.50 \\
14.50\end{array}$ & $\begin{array}{r}13.33 \\
2.86 \\
10.00 \\
13.50 \\
17.00\end{array}$ & $\begin{array}{r}13.79 \\
3.26 \\
10.00 \\
13.50 \\
18.00\end{array}$ & $\begin{array}{r}9.99 \\
3.14 \\
6.00 \\
10.00 \\
14.00\end{array}$ \\
\hline $\begin{array}{c}\text { Fat \% } \\
\text { SD } \\
\text { P10 } \\
\text { P50 } \\
\text { P90 }\end{array}$ & $\begin{array}{l}3.84 \\
0.60 \\
3.13 \\
3.77 \\
4.69\end{array}$ & $\begin{array}{l}3.51 \\
0.52 \\
2.87 \\
3.49 \\
4.15\end{array}$ & $\begin{array}{l}3.57 \\
0.66 \\
2.76 \\
3.56 \\
4.38\end{array}$ & $\begin{array}{l}4.10 \\
0.96 \\
3.13 \\
3.90 \\
5.37\end{array}$ & $\begin{array}{l}3.51 \\
0.77 \\
2.60 \\
3.48 \\
4.50\end{array}$ & $\begin{array}{l}3.69 \\
0.52 \\
2.87 \\
3.65 \\
4.51\end{array}$ & $\begin{array}{l}4.22 \\
1.07 \\
3.07 \\
4.06 \\
5.55\end{array}$ & $\begin{array}{l}3.50 \\
0.66 \\
2.72 \\
3.48 \\
4.33\end{array}$ & $\begin{array}{l}3.53 \\
0.68 \\
2.82 \\
3.46 \\
4.31\end{array}$ \\
\hline $\begin{array}{l}\mathrm{LS} \\
\text { P10 } \\
\text { P50 } \\
\text { P90 }\end{array}$ & $\begin{array}{l}4.55 \\
4.20 \\
5.94 \\
9.32\end{array}$ & $\begin{array}{l}2.20 \\
3.85 \\
4.77 \\
6.85\end{array}$ & $\begin{array}{l}3.92 \\
3.85 \\
5.25 \\
8.21\end{array}$ & $\begin{array}{l}4.03 \\
3.49 \\
5.17 \\
8.25\end{array}$ & $\begin{array}{l}3.35 \\
3.77 \\
4.85 \\
7.66\end{array}$ & $\begin{array}{l}4.93 \\
4.14 \\
6.23 \\
9.41\end{array}$ & $\begin{array}{l}3.94 \\
4.20 \\
5.29 \\
7.84\end{array}$ & $\begin{array}{l}4.74 \\
3.77 \\
5.45 \\
9.20\end{array}$ & $\begin{array}{l}4.21 \\
4.63 \\
6.54 \\
8.94\end{array}$ \\
\hline
\end{tabular}




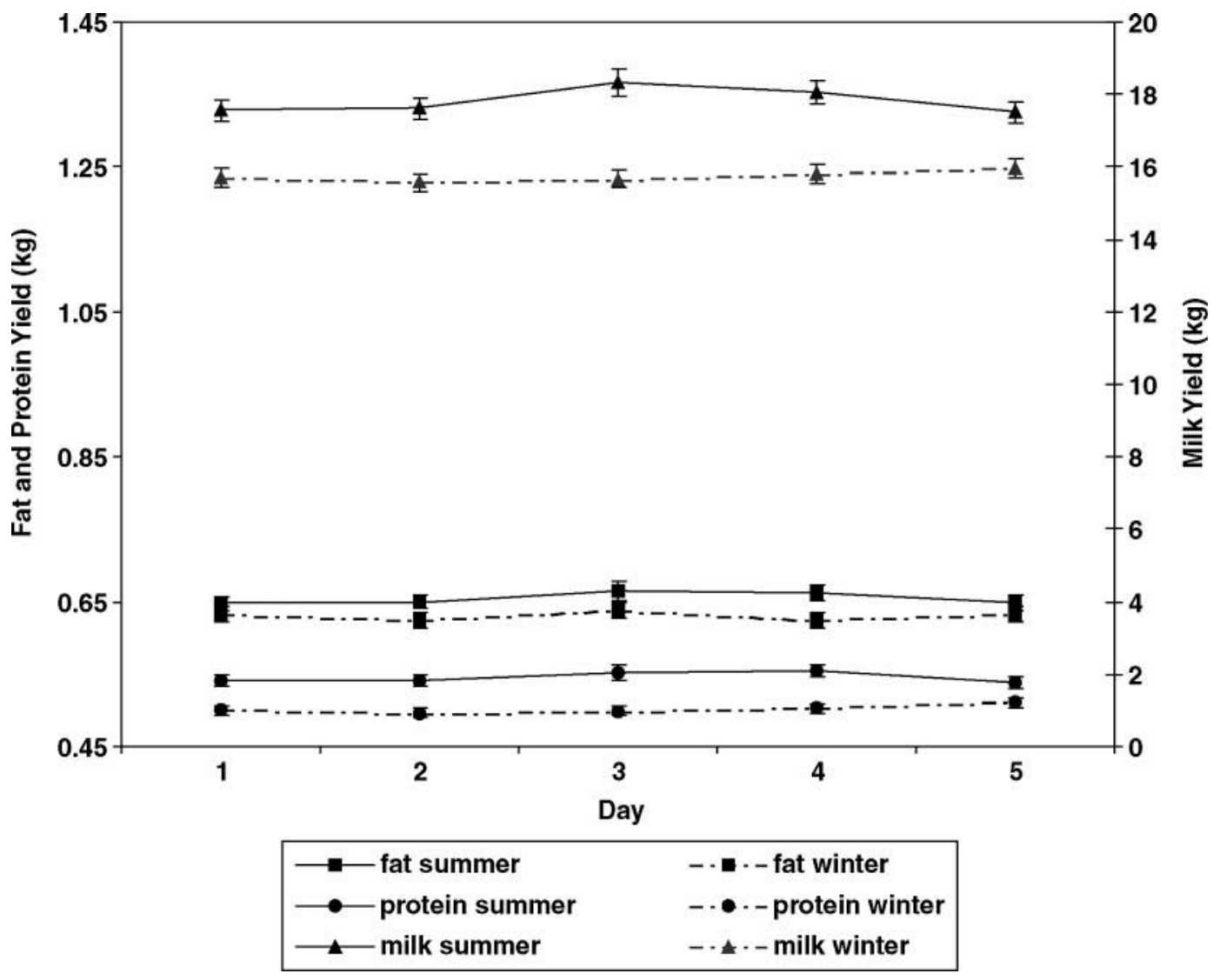

Figure 5. Mean $\pm \mathrm{SE}$ of milk, fat, and protein yields $(\mathrm{kg})$ in summer and winter over a 5 -d sampling period of 2 herds milked $2 \times$.

at the afternoon milking to a peak at the evening milking, then decrease through to the morning milking. The protein percentage had less variability than the fat percentage from milking to milking in both the $2 \times$ and $3 \times$ herds, in agreement with Gilbert et al. (1973) and Syrstad (1977).

The fat and protein patterns displayed the most consistency over the 5 -d sampling period in comparison with milk yield results in both $2 \times$ and $3 \times$ herds (Figures 1 and 2). The DHI program accounted for this diurnal variation by applying correction factors to the single-milking measurements of $2 \times$ herds by using the alternating a.m.-p.m. test scheme.

The SCC results of the $2 \times$ and $3 \times$ herds (Figures 3 and 4 , respectively) illustrate that throughout the 5 -d sampling period, no consistent diurnal variation was present; however, morning milkings of the $3 \times$ herds (Figure 4) had the lowest value each day. Although the herd in this study was a $3 \times$ herd, these results agree with Cullen (1967), who found that the mean SCC for 16 cows sampled twice daily over $5 \mathrm{~d}$ was always lower at the morning than the evening milking. A similar pattern was reported by Syrstad and Ron (1978), who collected consecutive milk samples from 14 cows over 2 wk. A recent study with 15 milking samples collected consecutively over $3 \mathrm{~d}$ reported no consistent milkingto-milking variation and could not explain the cause of the variation (De Vries et al., 2007). Producers should not rely on single test-day SCC results when managing mastitis.

Diurnal variation was not always consistent for milk yield, fat and protein percentages, and SCC. Milking period measurements can peak or drop drastically for various reasons, and if a DHI test day is performed at one of these milkings, the results of that test day can misinform the producer. This supports the intention of using daily milk weight data or multiple-day means in the DHI program at more frequent intervals than the present test-day plans. Although in-line daily measurements of fat and protein are not currently available from milking equipment, it is a technology that is foreseeable in the future (Miglior et al., 2006).

\section{Descriptive Statistics for Milk Yield, Fat and Protein Percentages, and LS}

The analysis of the 5-d sampling period allowed examination of milk yield, fat and protein percentages, 


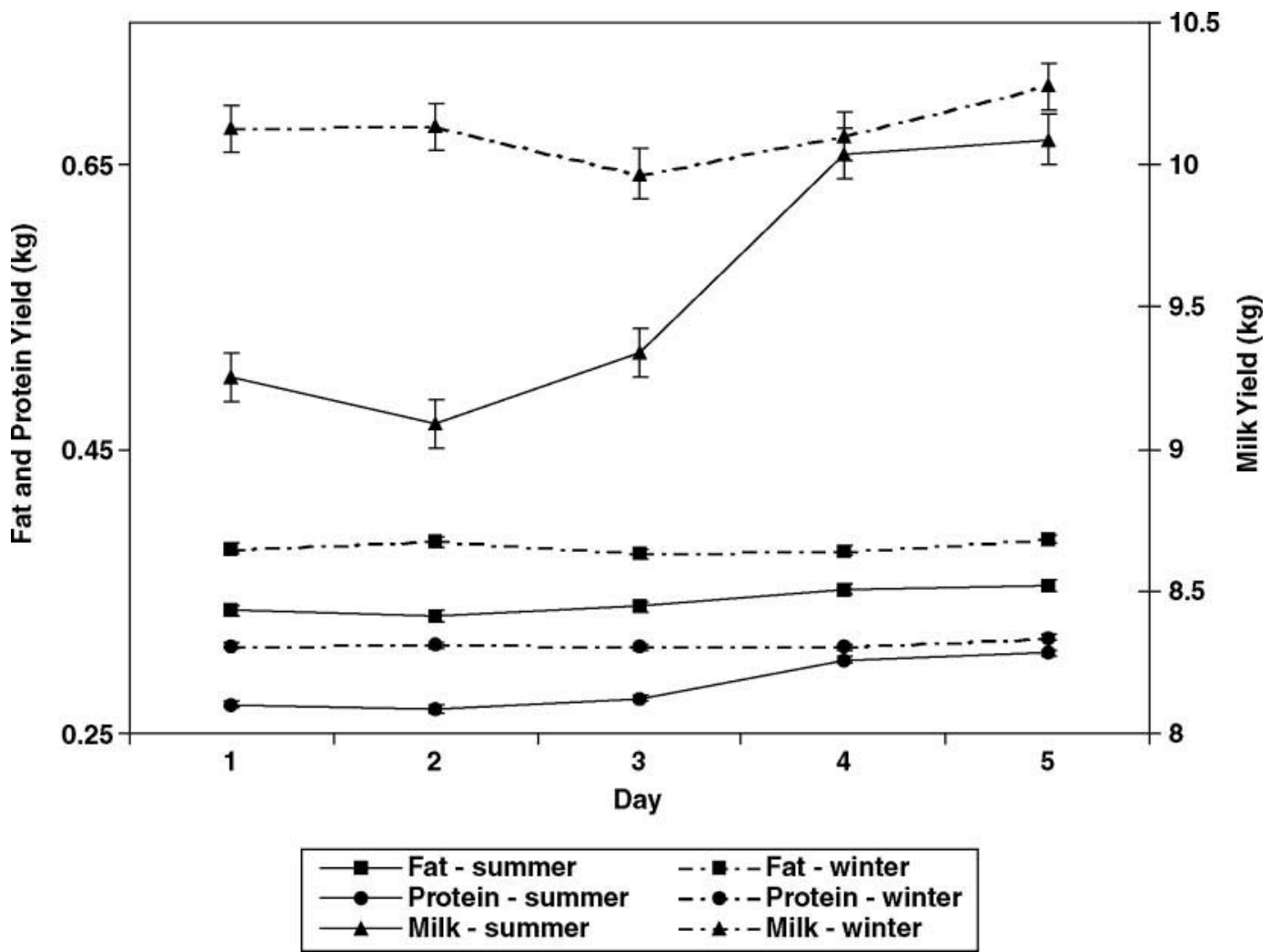

Figure 6. Mean $\pm \mathrm{SE}$ of milk, fat, and protein yields $(\mathrm{kg})$ in summer and winter over a 5-d period in a herd milked $3 \times$.

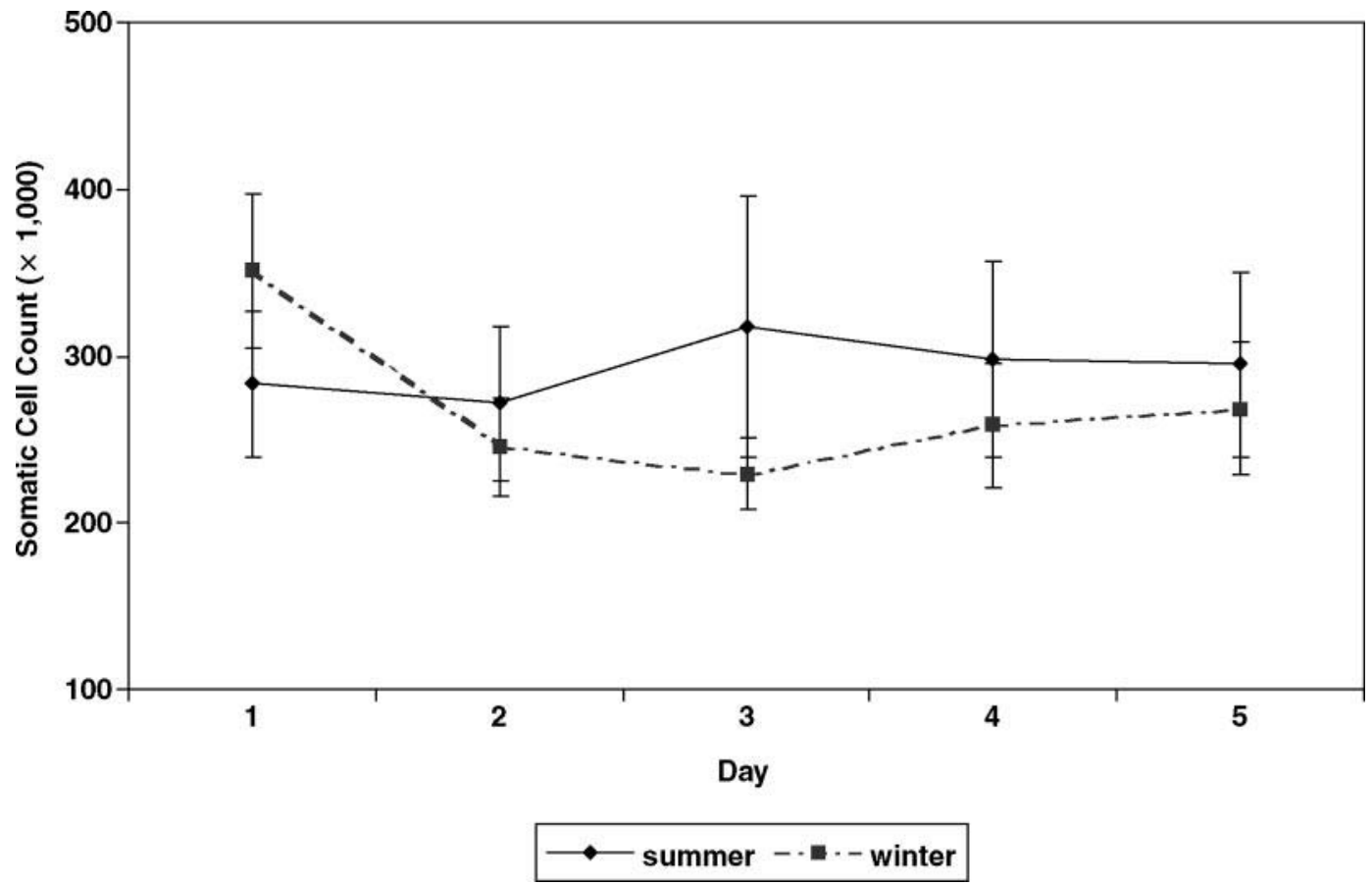

Figure 7. Mean $\pm \mathrm{SE}$ of SCC weighted with milk yield in summer and winter over a 5 -d period of 2 herds milked $2 \times$. 


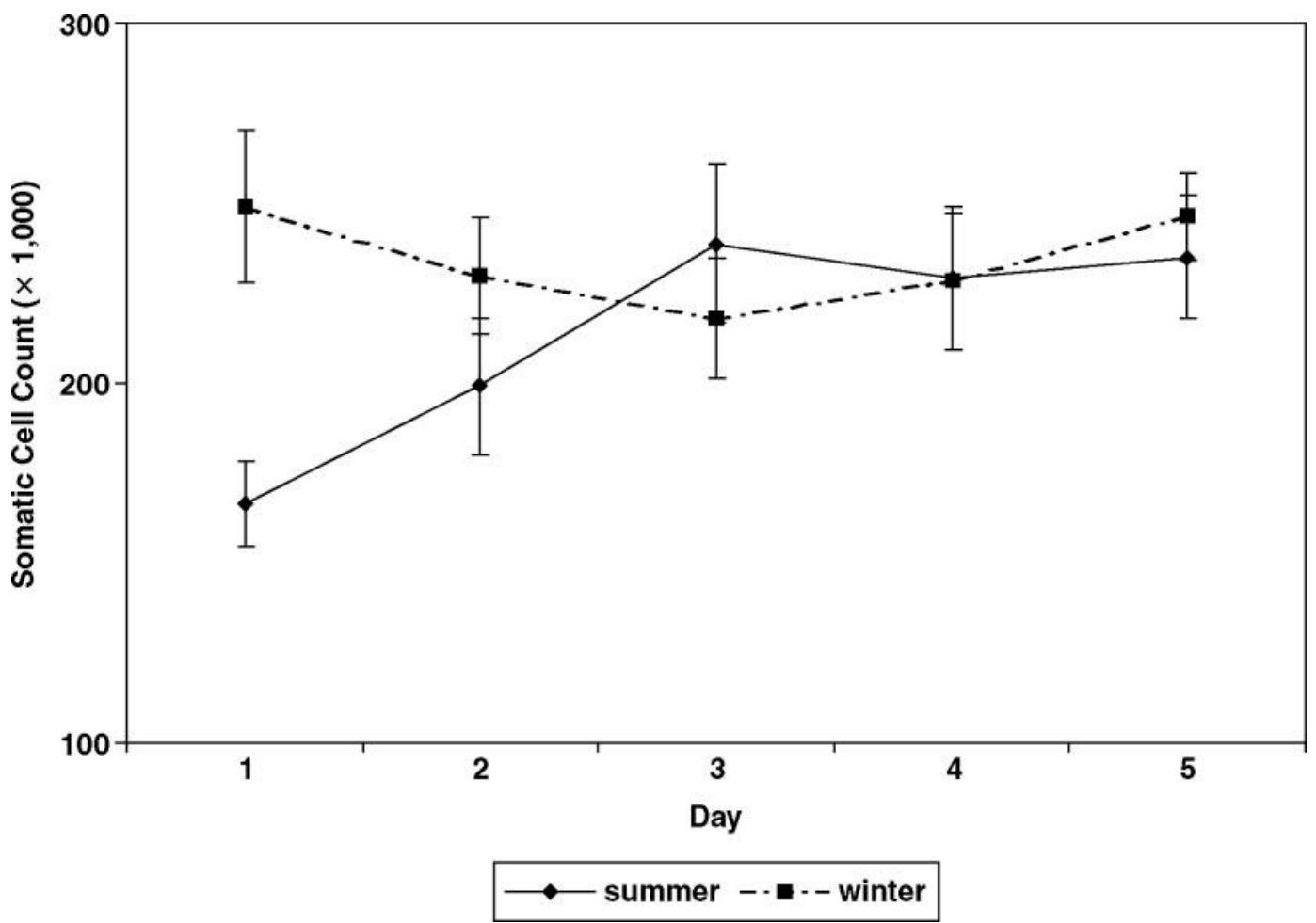

Figure 8. Mean $\pm \mathrm{SE}$ of SCC weighted with milk yield in summer and winter over a 5 -d period in a herd milked $3 \times$.

Table 3. Final linear regression model of seasonality for fat and protein yield per day

\begin{tabular}{|c|c|c|}
\hline \multirow[b]{2}{*}{ Variable } & \multicolumn{2}{|c|}{ Coefficient $\pm \mathrm{SE}$} \\
\hline & Fat & Protein \\
\hline Intercept & $-0.020 \pm 0.047$ & $-0.174 \pm 0.052$ \\
\hline Summer & $0.060 \pm 0.024$ & $0.072 \pm 0.023$ \\
\hline Winter & Referent & Referent \\
\hline Lactation 1 & $0.102 \pm 0.023^{*}$ & $0.117 \pm 0.027$ * \\
\hline Lactation 2 & $0.079 \pm 0.029$ & $0.068 \pm 0.027$ \\
\hline Lactation 3 & Referent & Referent \\
\hline Early DIM & $0.519 \pm 0.029^{*}$ & $0.333 \pm 0.028^{*}$ \\
\hline Mid DIM & $0.402 \pm 0.028^{*}$ & $0.291 \pm 0.026^{*}$ \\
\hline Late DIM & Referent & Referent \\
\hline \multicolumn{3}{|l|}{ Lactation 1 by } \\
\hline Summer & $-0.215 \pm 0.034^{*}$ & $-0.196 \pm 0.033^{*}$ \\
\hline Winter & Referent & Referent \\
\hline \multicolumn{3}{|l|}{ Lactation 2 by } \\
\hline Summer & $-0.093 \pm 0.036$ & $-0.081 \pm 0.035$ \\
\hline Winter & Referent & Referent \\
\hline Lactation $\geq 3$ & Referent & Referent \\
\hline \multicolumn{3}{|l|}{ Lactation 1 by } \\
\hline Early DIM & $-0.380 \pm 0.041^{*}$ & $-0.338 \pm 0.039^{*}$ \\
\hline Mid DIM & $-0.275 \pm 0.041^{*}$ & $-0.228 \pm 0.038^{*}$ \\
\hline Late DIM & Referent & Referent \\
\hline \multicolumn{3}{|l|}{ Lactation 2 by } \\
\hline Early DIM & $-0.125 \pm 0.045$ & $-0.073 \pm 0.043$ \\
\hline Mid DIM & $-0.235 \pm 0.040^{*}$ & $-0.179 \pm 0.037^{*}$ \\
\hline Late DIM & Referent & Referent \\
\hline
\end{tabular}

${ }^{*} P<0.01$. and $\mathrm{LS}$ values throughout lactations 1,2 , and $\geq 3$ and at each stage of DIM. The milk yield pattern of the $2 \times$ and $3 \times$ herds (Tables 1 and 2, respectively) followed a typical lactation curve, with yield means increasing from early to mid lactation and then decreasing from mid to late lactation across all parities. Mean fat and protein percentages of the $2 \times$ and $3 \times$ herds tended to follow the typical component curves, opposite the milk yield trend, decreasing in early lactation and rising again as DIM increased (Schutz et al., 1990). No previous studies have reported the standard deviations of milk yield and fat and protein percentages per milking. Syrstad (1977) calculated standard deviations within cows and found a milk yield of $1.56 \mathrm{~kg}$, and fat and protein percentages of 0.36 and 0.08 , respectively. Nonetheless, direct comparison with the results of the present study was not possible.

Research is limited on the association of lactation number and stage of lactation with LS. Previous literature reported that LS is usually higher at the beginning of lactation for first-lactation cows but higher at the end of lactation for cows in second lactation or greater (Schutz et al., 1990). The results of the current study support these findings in both the $2 \times$ and $3 \times$ herds for first-lactation cows, but only the second-lactation cows in $3 \times$ herds and third-lactation cows in $2 \times$ herds had higher LS at the end of lactation. The LS was higher 
in early and late DIM relative to mid lactation in firstand second-lactation cows, whereas cows in third and greater lactation had the highest LS mean in mid lactation. Bodoh et al. (1976) analyzed SCC by lactation number by dividing lactations into 5 DIM classes, and found that younger cows had lower SCC than older cows. The results of both the $2 \times$ and $3 \times$ herds agreed with the report of Bodoh et al. (1976) that LS increased as lactation number increased.

Tracking cow SCC is very important for the monitoring of udder health (Dohoo and Meek, 1982; Salsberg et al., 1984), yet there were no direct implications for collection of SCC from this study. The differences among various studies indicate that there is not a definite pattern throughout lactations and lactation numbers.

\section{Milk Fat Variation Mixed Model}

In this study, only milking period had a significant effect on fat percentage in herds milked $2 \times$, with the morning milking having a slightly negative association with fat percentage. Our study agrees with previous findings for milking period, but others have found associations with day and cow, as well as interactions between these variables (Gilbert et al., 1973; Syrstad, 1977). We expected that feeding frequency and feed push-up would have effects on milk fat percentage, because Sutton et al. (1985) reported that milk fat increased by more frequent feeding or feed push-up. Nevertheless, neither feeding nor feed push-up variables had a significant effect on milk fat percentage. The present study investigated effects at the herd level under field conditions, and this may have contributed to the difference in findings.

\section{Milk Fat Variance Components}

The variance components in both $2 \times$ and $3 \times$ herds were as expected, with the majority of the variation contributed by herd. The variance attributable to herd came from each herd having distinct management, environmental, and nutritional characteristics, which contributed to milk fat variation. The residual error indicated that there was a large amount of variability in milk fat percentage that was not explained by the 3 sources evaluated in this analysis. The milking period (morning vs. evening) contributed a considerable amount to milk fat percentage variation. The milking period variable did not consider the interval between milkings in this study, which could influence milk fat variation. The main reason this was excluded from the study was because the study herds were free stalls with milking parlors. It is difficult to monitor the order that cows come into the parlor for milking, and the milking intervals for individual cows can vary from milking to milking (Schaeffer et al., 2000).

\section{Seasonality of Milk Yield, Fat and Protein Yields, and $L S$}

The greater milk yield in summer compared with winter in the $2 \times$ herds (Figure 5) agreed with Ng-KwaiHang et al. (1984) and Sargeant et al. (1998). Sargeant et al. (1998) indicated that fat and protein yields followed a seasonal pattern similar to milk yield, which was observed only in the $2 \times$ herds (Figure 5). The opposite result for the $3 \times$ herd with respect to milk, fat, and protein (Figure 6) was unexpected; however, no previous research exists on seasonality with $3 \times$ herds with which to compare the results.

The significantly higher yields of fat and protein in winter for lactation 1 was unexpected, and was not found in previous literature. Further pairwise comparison of lactations within seasons indicated that in summer, but not in winter, there were significant differences between parities, except with the first lactation. Seasonal changes in management of first-lactation cows on the 3 farms were not considered and could have contributed to the difference. Furthermore, weather conditions and environmental temperatures could have affected production. Heat stress can affect the milk yield; however, a differential effect on parity groups was not expected (Ravagnolo and Misztal, 2002). The small number of herds in the present study makes it possible that the effects of season may have been confounded by changes in management, nutrition, or herd population. Further examination of the $3 \times$ herds for differences in seasonality are warranted to determine whether the results described here are common to other $3 \times$ herds, and if so, to investigate the factors contributing to seasonality in $3 \times$ herds. Previous studies investigated factors contributing to seasonality in milk and milk components in $2 \times$ herds and determined that seasonal variation was due to environmental conditions ( $\mathrm{Ng}$-Kwai-Hang et al., 1984; Sargeant et al., 1998) and nutrition changes (Agabriel et al., 1993).

Of the 3 study herds, only 1 herd (Figure 8) demonstrated a seasonal trend, with higher SCC in the summer months than in the winter months (Bodoh et al., 1976; Salsberg et al., 1984). The other 2 herds in the current study did not show seasonal differences. Other management and environmental factors associated with mastitis infection are likely more influential than effects of season.

Previous studies (Bodoh et al., 1976; Salsberg et al., 1984) used test-day results provided by milk-recording organizations to examine seasonal variations, whereas the current study used 2 periods of 5 -d sampling to de- 
termine seasonal effects. This could be a limitation of the current study, because it was only a small portion of time within a whole season, whereas milk recording organizations collect data throughout the entire year.

\section{CONCLUSIONS}

The first objective of this study was to examine milking-to-milking variations in milk, fat, and protein yields and in SCC in $2 \times$ and $3 \times$ herds across Canada. Although the $2 \times$ herds showed many similarities with previous studies, results provided a preliminary look at diurnal variation within $3 \times$ herds. These results support the need for more frequent data collection from farms to use in the DHI program for test-day calculations. Component values followed typical lactation curve patterns within lactations, whereas LS had contrasting results from previous studies. For the second objective, to investigate the factors that affect milk fat percentage, herd effects explained the majority of the variation, with some variation explained by milking period. The final objective of this study was to examine variations in milk, milk components, and SCC between summer and winter. The $3 \times$ herds had results opposite those of the $2 \times$ herds, with milk fat and protein yields being slightly higher in the winter vs. summer months in the $3 \times$ herds. Further seasonality research may be warranted to investigate the factors in $3 \times$ herds contributing to seasonality.

\section{ACKNOWLEDGMENTS}

The authors thank Dairy Gen (Guelph, Ontario, Canada) and the Natural Sciences and Engineering Research Council of Canada (Ottawa, Ontario, Canada) for funding this research. The participating producers, the staff and technicians at CanWest DHI, and the research technicians are gratefully acknowledged for their valuable assistance in collecting the data.

\section{REFERENCES}

Agabriel, C., J. B. Coulon, G. Marty, and B. Bonaiti. 1993. Changes in fat and protein concentrations in farms with high milk production. J. Dairy Sci. 76:734-741.

Bodoh, G. W., W. J. Battista, and L. H. Schultz. 1976. Variation in somatic cell counts in dairy herd improvement milk samples. J. Dairy Sci. 59:1119-1123.

Cullen, G. A. 1967. Short term variations in the cell count of cows' milk. Vet. Rec. 80:649-653.
De Vries, A., D. R. Bray, and R. P. Natzke. 2007. Cow somatic cell counts can really jump around. Hoard's Dairyman. 152:96-97.

Dohoo, I. R., and A. H. Meek. 1982. Somatic cell counts in bovine milk. Can. Vet. J. 23:119-125.

Everett, R. W., and L. H. Wadell. 1970. Sources of variation affecting the difference between morning and evening daily milk production. J. Dairy Sci. 53:1424-1429.

Gilbert, G. R., G. L. Hargrove, and M. Kroger. 1973. Diurnal variation in milk yield, fat yield, milk fat percentage and milk protein percentage of Holstein-Friesian cows. J. Dairy Sci. 56:409-410.

Harmon, R. J. 1994. Physiology of mastitis and factors affecting somatic cell counts. J. Dairy Sci. 77:2103-2112.

Jenkins, T. C., and M. A. McGuire. 2006. Major advances in nutrition: Impact on milk composition. J. Dairy Sci. 89:1302-1310.

Klusmeyer, T. H., M. R. Cameron, G. C. McCoy, and J. H. Clark. 1990. Effects of feed processing and frequency of feeding on ruminal fermentation, milk production, and milk composition. J. Dairy Sci. 73:3538-3543.

Miglior, F., S. de Roos, Z. Liu, S. Mattalia, L. R. Schaeffer, A. Tondo, and P. VanRaden. 2006. Report of the ICAR working group on lactation calculation methods: A survey on milk recording strategies in dairy cattle. Pages 145-149 in Final Programme and Technical Presentations, 35th ICAR Session and Interbull Meeting, Kuopio, Finland. EAAP, Rome, Italy.

Ng-Kwai-Hang, K. F., J. F. Hayes, J. E. Moxley, and H. G. Monardes. 1984. Variability of test-day milk production and composition and relations of somatic cell counts with yield and compositional changes of bovine milk. J. Dairy Sci. 67:361-366.

Putnam, D. N., and H. C. Gilmore. 1970. Factors to adjust milk production to a 24 -hour basis when milking intervals are unequal. J. Dairy Sci. 53 (Suppl.):685. (Abstr.)

Raubertas, R. F., and G. E. Shook. 1982. Relationship between lactation measures of somatic cell concentration and milk yield. J. Dairy Sci. 65:419-425.

Ravagnolo, O., and I. Misztal. 2002. Effect of heat stress on nonreturn rate in Holsteins: Fixed-model analyses. J. Dairy Sci. 85:3101-3106.

Salsberg, E., A. H. Meek, and S. W. Martin. 1984. Somatic cell counts: Associated factors and relationship to production. Can. J. Comp. Med. 48:251-257.

Sargeant, J. M., K. E. Leslie, M. M. Shoukri, S. W. Martin, and K. D. Lissemore. 1998. Trends in milk component production in dairy herds in Ontario: 1985-1994. Can. J. Anim. Sci. 78:413-420.

SAS Institute. 2000. SAS/STAT User's Guide, Version 8. SAS Inst., Inc., Cary, N.C.

Schaeffer, L. R., and J. Jamrozik. 1996. Multiple-trait prediction of lactation yields for dairy cows. J. Dairy Sci. 79:2044-2055.

Schaeffer, L. R., J. Jamrozik, R. Van Dorp, D. F. Kelton, and D. W. Lazenby. 2000. Estimating daily yields of cows from different milking schemes. Livest. Prod. Sci. 65:219-227.

Schutz, M. M., L. B. Hansen, and G. R. Steuernagel. 1990. Variation of milk, fat, protein and somatic cells for dairy cattle. J. Dairy Sci. 73:484-492.

Sutton, J. D. 1989. Altering milk composition by feeding. J. Dairy Sci. 72:2801-2814.

Sutton, J. D., W. H. Broster, D. J. Napper, and J. W. Siviter. 1985. Feeding frequency for lactating cows: Effects on digestion, milk production and energy utilization. Br. J. Nutr. 53:117-130.

Syrstad, O. 1977. Day-to-day variation in milk yields, fat content and protein content. Livest. Prod. 4:141-151.

Syrstad, O., and I. Ron. 1978. Day-to-day variation in cell counts in milk. Nord. Vet. Med. 30:192-198. 